J. Kyushu Dent. Soc. 51 ( 5 ): 521 542, 1997.

\title{
Histological Study of Nerve Distribution around Different Implant Materials in Dogs
}

\author{
Yi-Huei Wang \\ Second Department of Prosthetic Dentistry (Director: Prof. Yasunari Uchida) \\ Department of Oral Pathology (Director: Prof. Hiroshi Fukuyama) \\ Kyushu Dental College, Kitakyushu, Japan
}

Key words : Dental implant/Innervation/3-D Reconstruction/Bone contact ratio/Dog

Accepted on August 25, 1997.

\section{Introduction}

Since they were developed three decades ago, dental implants have provided a new way of restoring missing teeth in dental clinical therapy. To date, endosteal implants have been the most commonly used.

Three terms, fibrointegration ${ }^{1)}$, osseointegration ${ }^{1)}$, and biointegration ${ }^{2)}$, were used to describe the relationships between the endosteal implants and their surrounding tissue ${ }^{3)}$. Because the osseointegration implants and biointegration implants give more stability resulting from the direct contact or bonding of bone tissue with the surface of the endosteal implant, they are suggested for use in current implant treatment. It is clear that successful implant supporting prostheses implants with good integration between bone and implants can provide a larger occlusal force than can conventional removable dentures ${ }^{4,5}$, although there is no significant difference in maximal occlusal force when comparing implant supporting overdentures with root supporting overdentures ${ }^{6}$.

Restoration of the normal masticatory function via implants should be aimed not only at the rehabilitation of occlusal force, but also the recovery of the sensory system around implants. This is because the sensory system can protect implants from occlusal overloading by transmitting external stimulation via the implants to the central nerve system (CNS), which in turn will regulate the masticatory movement. Without this protecting mechanism, overloaded implants will fail either by a breakdown in surrounding bone tissue ${ }^{7)}$ or by a fracture of the fixture.

In natural teeth, it has been shown histologically that the sensory terminals or receptors ${ }^{8,9)}$ can receive stimulation from the outside and transmit the information to the CNS where it may bring about a regulating response. Many neurophysiological studies $^{10-12)}$ have described the sensory input system in the periodontal ligament (PDL) and explained the mechanism of tactile function in natural teeth. Reinnervation in the periodontal ligament after reimplantation has been investigated by using light and electron microscopy ${ }^{13)}$ and has been detected by electrophysiological recordings ${ }^{14)}$. However, the implant is different from the 
natural tooth in that the PDL is absent. Whether they also are different in terms of neurophysiological function needs to be clarified.

There are many neurophysiological reports written about implant-associated sensory input mechanism ${ }^{6,121521)}$. When implants were compared with natural teeth, four perceptions were obtained: 1 ) duller, more difficult to localize, and more persisten $\mathrm{t}^{17}$; 2 ) higher tactile pressure threshold ${ }^{6,15,16)} ; 3$ ) lower conductive speed $^{20)} ; 4$ ) more difficult to inhibit mastication $^{18}$. Unfortunately, there are few histological data ${ }^{22,23)}$ that deals with nerves as they relate to this mechanism.

Neuropeptides, such as Calcitonin gene-related peptide (CGRP), Neuropeptide Y (NPY) and Substance $\mathrm{P}$ (SP), are released from afferent nerve terminals and are involved in neurogenic inflammation, tissue repair, and bone metabolism ${ }^{24,25)}$. These findings underscore the importance of histological study of nerve tissue in the peri-implant area.

The purpose of this study was to investigate the distribution, morphology, and the temporal changes of nerve tissue around the three kinds of implant materials.

\section{Materials and methods}

\section{Implant materials}

Three kinds of implant materials that have been used in clinical practice were obtained from the Kyocera Company (Kyoto, Japan). They were specially designed cylindrical shapes, $3.0 \mathrm{~mm}$ in diameter and $5.0 \mathrm{~mm}$ in height, to make them suitable for surgery on dogs. Each kind of implant has its own commercial name and has specific surface characteristics, which were observed with scanning electron microscope (SEM, JEOL, JSM T-300) as follows:

1. Bioceram ${ }^{\circledR}(\mathrm{BIO}): \mathrm{Al}_{2} \mathrm{O}_{3}$, single crystal sapphire implant (Fig. 1-A)

2. FINAFIX ${ }^{\circledR F X}$ ) : Titanium alloy (Ti-6Al-4V) implant with an anode-oxidized layer of $1350 \AA \sim 1400 \AA$ in thickness ${ }^{26)}$ (Fig. 1-B)

3. FINATITE $^{\circledR}(\mathrm{HAC})$ : Titanium alloy $(\mathrm{Ti}-6 \mathrm{Al}-4 \mathrm{~V})$ implant coated with hydroxyapatite by using High-velocity-flame-spray technique ${ }^{26)}$ (Fig. 1-C)

Before the surgery, all implants were sterilized at $180^{\circ} \mathrm{C}$ for two hours according to the manufacturer's instructions.
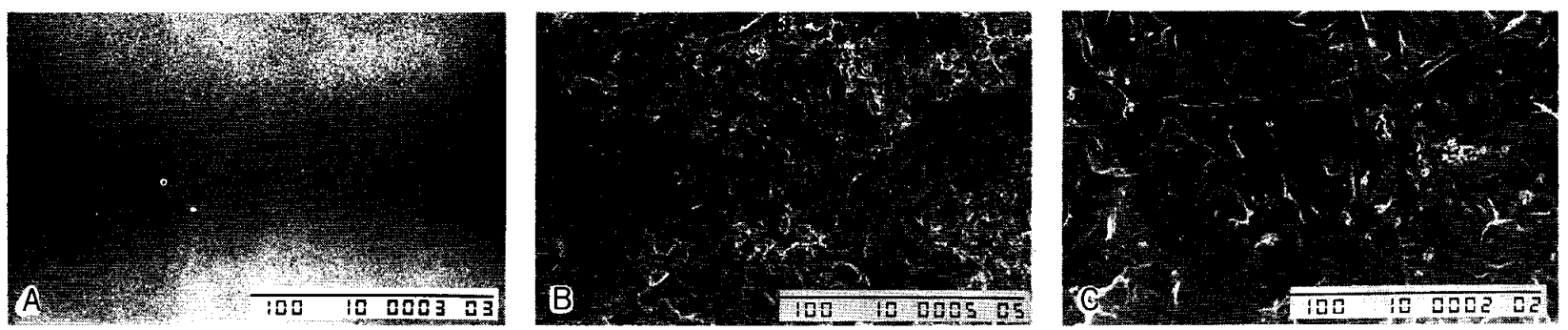

Fig. 1 Scanning electron micrographs of the surface characteristic on the three kinds of Kyocera implants.

A, BIO implant; B, FFX implant and C, HAC implant. Bar represents $100 \mu \mathrm{m}$. 
A.
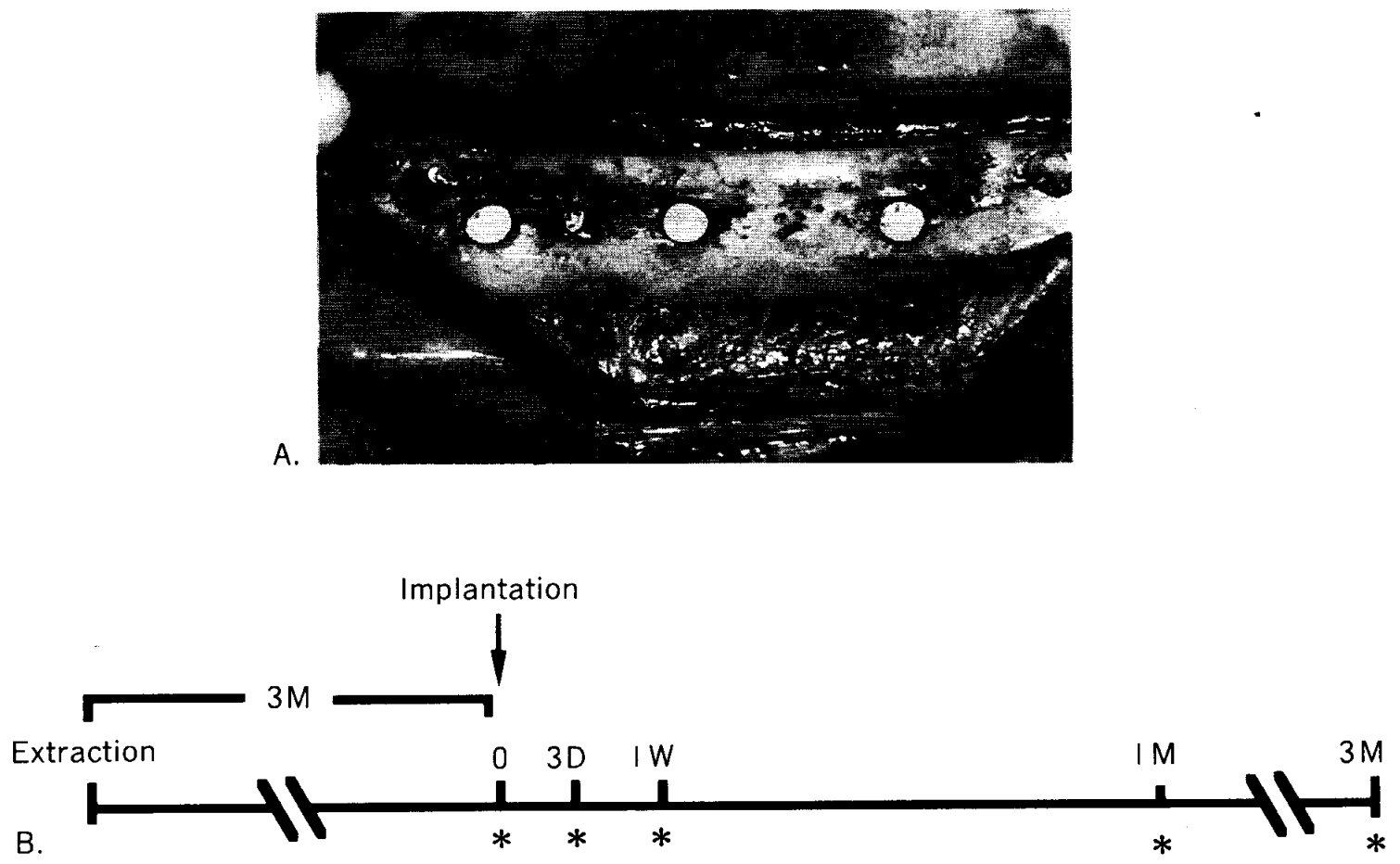

Fig. 2 A : A photograph after implantation on the mandible of a dog. Left, BIO implant; Middle, FFX implant and right, HAC implant.

$\mathrm{B}$ : The experimental schedule from extraction to the finish of the longest observing period. $D$, day; $W$, week; $M$, month; and stars (*) represent the time to sacrifice the dogs.

\section{Experimental design and surgical procedure}

Twelve healthy adult mongrel dogs (seven males and five females) were used in the present study. After sedation with intramuscular injections of Selactor ${ }^{\circledR}(0.1 \mathrm{ml} / \mathrm{kg}$, xylazine hydrochloride, Bayer, Germany) and Atropine $(0.5 \mathrm{mg} / 15 \mathrm{~kg}$, atropine sulfate, Tanabe, Japan), surgery was performed under general anesthesia induced by intravenous injection of Nembutal $^{\circledR}(0.33 \mathrm{ml} / \mathrm{kg}$, pentobarbital sodium, Abbot, USA). Local anesthesia by intraoral injection of Xylocaine ${ }^{\circledR} \quad(1.8 \mathrm{ml}, 20 \mathrm{mg}$ Lidocaine hydrochloride $/ 0.0125 \mathrm{mg}$ epinephrine, Fujisawa, Japan) also was applied.

Following a healing period of three months after extraction of bilateral 2nd, 3rd, 4th premolars and 1st molars from mandibles, 60 implants without a superstructure were inserted into the mandibular areas of $10 \mathrm{dogs}$ (Fig. 2-A) in line with the standard surgical procedure for cylindrical implants, to obtain initial fixation. The flaps were closed to allow submerged healing and infection was prevented by intramuscular injection of Cefatrexyl ${ }^{\circledR}(20 \mathrm{mg} / \mathrm{kg}$, cefaperine sodium, Bristol-Myers, USA.). Three days, one week, one month and three months later, the dogs with implants were re-anesthetized, administered Heparin sodium injection- $\mathrm{N}^{\circledR}$ $(20 \mathrm{mg} / \mathrm{kg}$, cefaperine sodium, Bristol-Myers, USA.) intravenously and perfused through the bilateral cervical arteries with the fixative, (a solution of $9 \%$ neutral buffered formalin, saturated picric acid, and $1 \%$ trichloroacetic acid) which was especially used before the nerve 


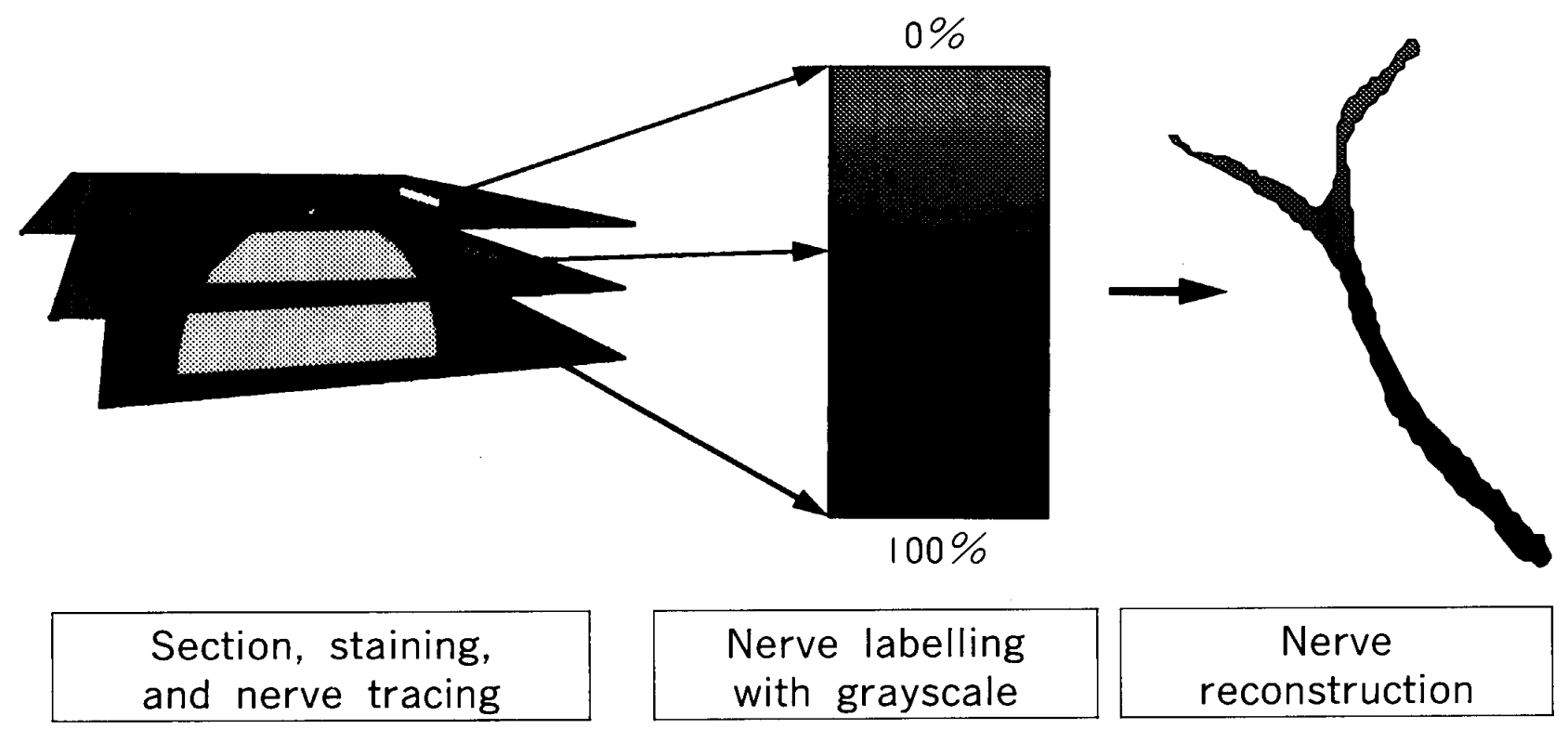

Fig. 3 Schematic diagram demonstrating the procedure of nerve reconstruction.

staining procedure. The mandibles with implants were removed and placed in the same fixative for two weeks. For controls, two dogs which did not receive any implants were killed three months after extraction to obtain their mandibles by the forgoing method. The time schedule of these experiment is illustrated in figure 2-B.

\section{Preparation of decalcified specimens}

After fixation, all specimens were hemisected longitudinally along the long axis of the implants in the mesio-distal plane and decalcified in the mixture of formic acid and trisodium citrate dihydrate. Once decalcification was completed, the implants were carefully removed from the specimens. After neutralization with $5 \%$ sodium sulfate, tissues were embedded in paraffin and serially sectioned at $15 \mu \mathrm{m}$. After deparaffinization, sections were stained by one of two methods: (1) hematoxylin and eosin (HE stain) and (2) Ueno's nerve staining method (nerve stain), a further modification of Powers-modified Ungewitter urea-silver nitrate $\operatorname{method}^{27)}$. The specimens were observed under a light microscope to investigate the sequential changes of nerve tissue around the implants.

\section{Reconstruction of nerve tissue in three-dimensional picture}

In the 3 months specimens, the serial sections stained with the urea-silver nitrate method were photographed at maginification $\times 2.5$. The negatives were digitized in a Macintosh ${ }^{\circledR}$ computer for the purpose of three-dimensional reconstruction. Each segment of nerve tissue and the outline of the implant were traced on the software of Photoshop $2.5^{\circledR}$; the areas thought to be nerve were simultaneously examined by light microscopy to confirm their identity. In the software of Illustrator $3.0^{\circledR}$, the traced lines used to express the nerve fibers were labeled in different degree of blackness from $0 \%$ to $100 \%$ and overlapped using the 


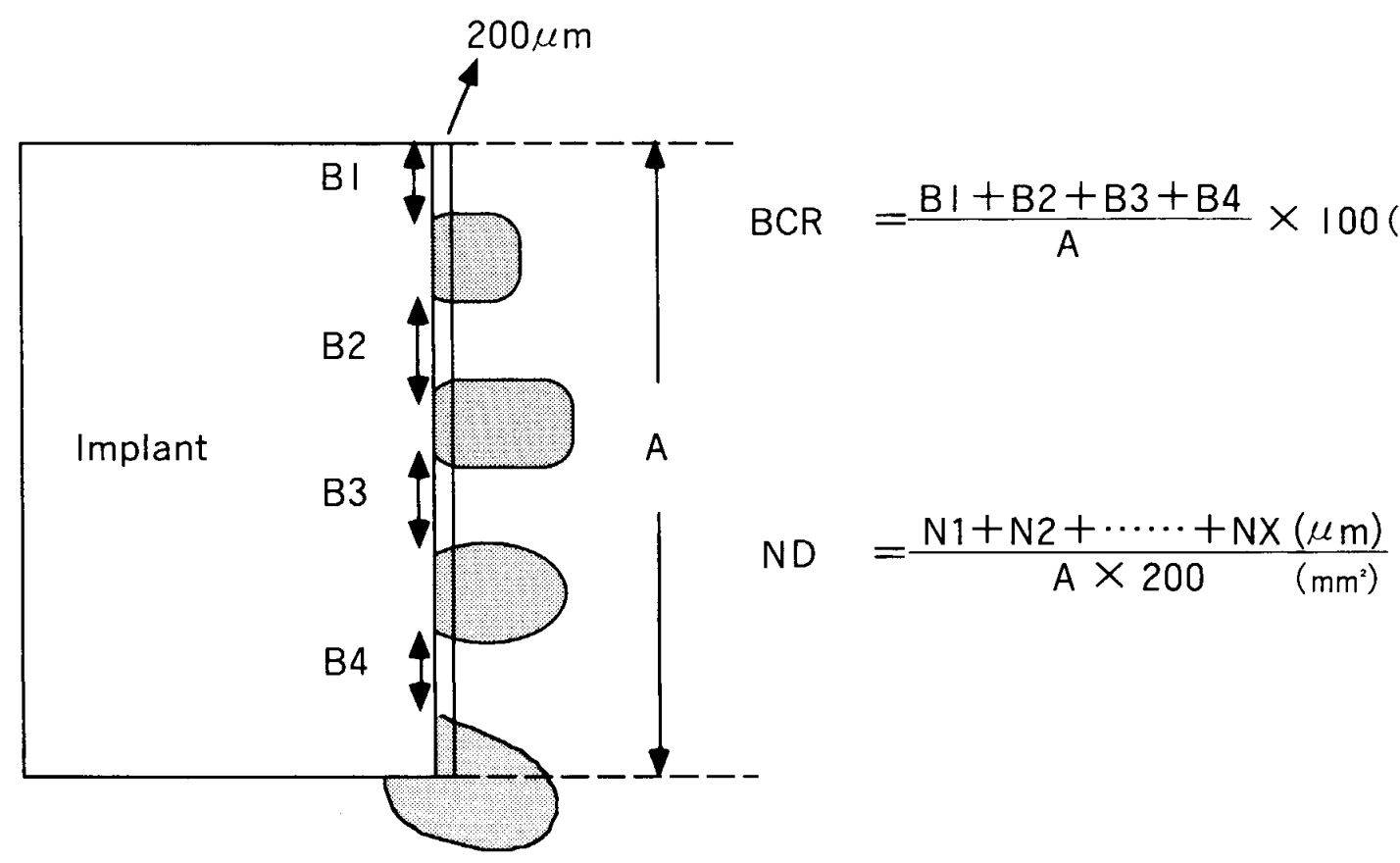

Fig. 4 Diagram to show the histomorphometric method.

The right is the formulas to calculate the BCR (in \%) and ND (in $\mu \mathrm{m} / \mathrm{mm}^{2}$ ). A, entire length of lateral wall at an implant (in $\mu \mathrm{m}) ; \mathrm{B}$, length of bone contact (in $\mu \mathrm{m}$ ); $\mathrm{N}_{1} \sim \mathrm{N}_{\mathrm{x}}$, the segmental length of nerve fiber (in $\mu \mathrm{m}$ ).

central line of implants as a reference point. The grade of blackness was determined according to the position in that specimen. In other words, the nearer nerve fibers are to the observer, the more lightly they were labeled (Fig. 3). In this way, the continuous morphology of the nerve fibers and their distributional pattern is revealed.

\section{Histomorphometric analysis}

In the cases of the three months' specimen, to quantify nerve fibers distribution and its relationship to the other tissue around implants, two histomorphometric analyses, the bone contact ratio and the density of nerve fibers ${ }^{28)}$, were calculated using a Vedio micrometer ${ }^{(1)}$ (Olympus, Japan) for linear measurements. Their formulas were defined as follow :

Bone contact ratio $(\mathrm{BCR})=$ (Length of direct bone contact with implant/length of entire implant) $\times 100 \%$

Nerve density $(\mathrm{ND})=$ Total length of nerve fibers in a zone $200 \mu \mathrm{m}$ which parallels the entire implant $(\mu \mathrm{m}) /$ Area of zone $\left(\mathrm{mm}^{2}\right)$

These fields are diagrammatically illustrated in Figure 4.

In the three month specimens, 4-6 implant sites were chosen to be measured from each kind of implant. From every implant site, five sections were chosen randomly. Then the averages of BCR and ND were calculated.

\section{Statistical evaluation}

The values of $\mathrm{BCR}$ and $\mathrm{ND}$ were expressed as mean $\pm \mathrm{SD}$. Comparisons of these 
measurements were made with Student's t test. For all tests, a level of significance of 0.05 was employed.

To evaluate the correlation of local $\mathrm{BCR}$ and $\mathrm{ND}$, those on every section were calculated and the data taken from three kinds of implants were mixed and then a regressive graph of local $\mathrm{BCR}$ to $\mathrm{ND}$ was plotted. In the same way, correlation between the average $\mathrm{BCR}$ to average ND in all implants also was evaluated and graphed. Correlation coefficients were all estimated by regressive analysis with a level of significance of 0.05 .

\section{Results}

All implants healed uneventfully following submerged installation. During the observation period, no gingival mucosa under which implants had been placed showed evidence of infection, swelling or gingival rupture.

\section{Histological observation}

Three months after tooth extraction, wounds were filled by bone tissue. Bone marrow showed fatty change, which made the wound site difficult to be distinguished from surrounding bone (Fig. 5). In these extracted areas, larger ascending nerve trunks with their surrounding connective tissue were found extending from the inferior alveolar nerve to the gingival mucosa. Except for the regions which nerve trunks passed through, there were not many nerve fibers found in these alveolar sockets (Fig. 5).

Three days after implantation, blood clots and bone fragments were still abundant in the space between the implant and the surrounding sound bone. Inflammatory cells, such as polymorphonuclear neutrophils (PMN), macrophages $(\mathrm{M} \phi)$ and lymphocytes, and fibroblasts (FIBs) also were abundant in the peri-implant area. Nerve fibers in the peri-implant area

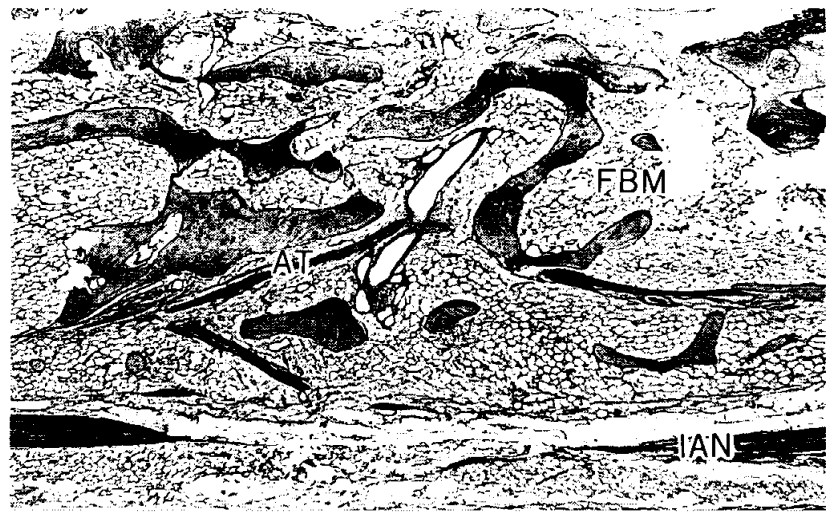

Fig. 5 Light micrograph of a 3 months' case after extraction section.

Bone marrow showed fatty change and a large ascending nerve trunk with their surrounding connective tissue were found from inferior alveolar nerve to the side of gingival mucosa. AT, ascending trunk; FBM, fatty bone marrow; IAN, inferior alveolar nerve. (Original magnification $\times$ 5 , nerve staining.)

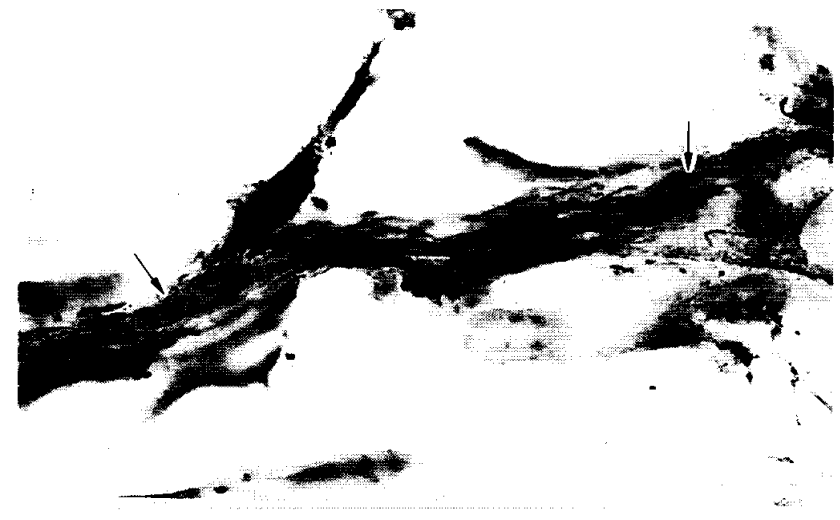

Fig. 6 Light micrograph of Wallerian degeneration (arrow) in a 3 days' case after implantation. (Original magnification $\times 400$, nerve staining.) 


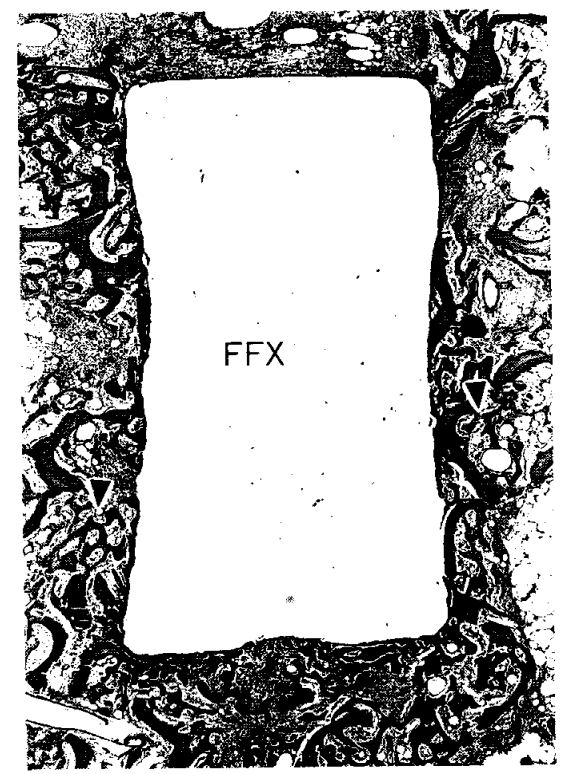

Fig. 7 Light micrograph showing the whole view of a FFX implant 1 week after implantation.

Osteoblast-associated woven bone formation (arrow) were found in the peri-implant area. (Original magnification $\times 5$, HE staining.)

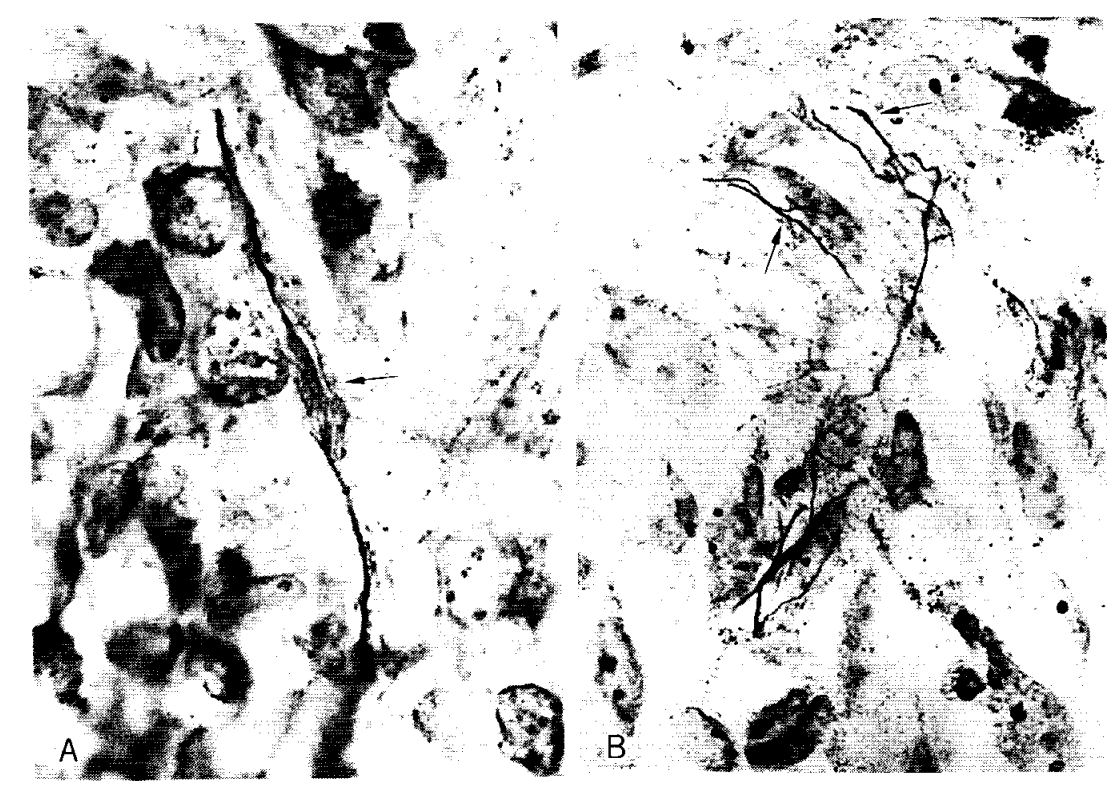

Fig. 8 Light micrograph of the regenerating nerve fibers 1 week after implantation.

A, the sprouting of a nerve fiber (arrow) was found in periimplant area. B, several thin, unmyelinated regenerating nerve fibers (arrow) extended in the peri-implant area. (Original magnification $\times 400$, nerve staining.)

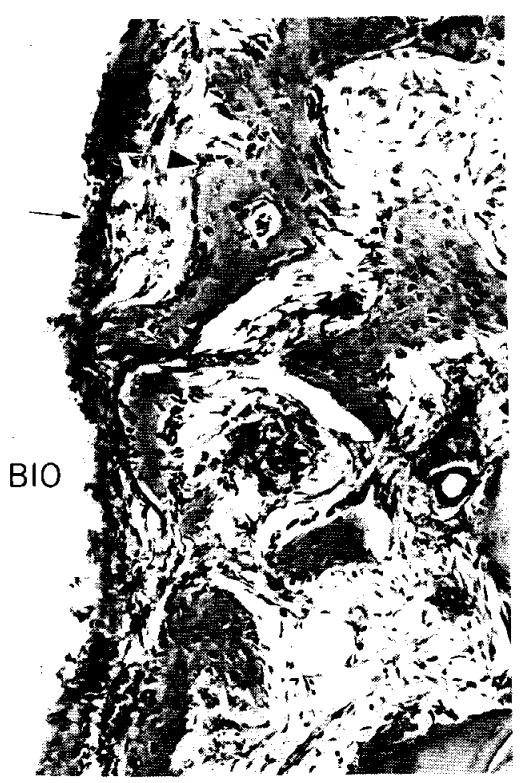

Fig. 9 Light micrograph of new bone formation in a 1 week's case of BIO implant.

Osteoblasts (arrow head) revealed the high activity of new bone forming. Fibrous tissue (arrow) interposed between the new bone and the implant. (Original magni-fication $\times 50, \mathrm{HE}$ staining.)

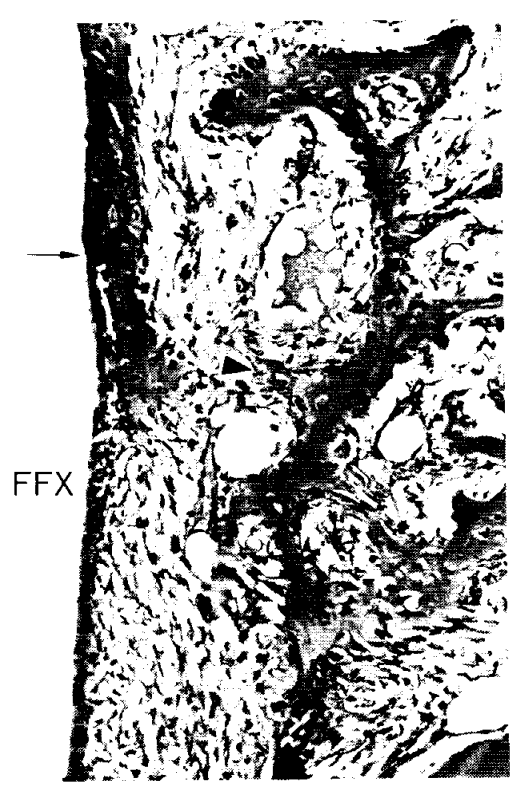

Fig. 10 Light micrograph of new bone formation in a 1 week's case of FFX implant.

Osteoblasts (arrow head) also revealed the high activity of new bone forming like Fig.9. One layer of cells (arrow) interposed between the new bone and the implant. (Original magnification $\times 50$, HE staining.) 
showed Wallerian degeneration ${ }^{29)}$, which is characterized by low-grade staining, beadlike changes, or segmentation of axonal fibers (Fig. 6). There was no difference among the three kinds of implants in histopathological findings.

One week after implantation, the volume of blood clots and the number of inflammatory cells decreased significantly. Osteoclast-associated bone fragment resorption and osteoblast-associated woven bone formation were found in peri-implant area (Fig. 7). In this period, bone trabeculae, consisting solely of osteoid, appeared and proliferated into the granulation tissue. Some neuronal degeneration persisted in the three day specimen. Within the granulation tissue bed in the intertrabecular spaces of new bone formation, regeneration of relatively thin fibers was observed (Fig. 8A \& B).

Differences in bone formation activities of osteoblasts were observed during this period. In BIO and FFX implants, new bone formation advanced from the side of the old bone towards the implants (Fig. 9, 10). HAC implants, exhibited the same behavior of osteoblasts as seen around $\mathrm{BIO}$ and FFX implants, but osteoblasts also came into line along the implant surface where they deposited osteoid (Fig. 11).

One month $\mathrm{HE}$ sections showed completion of bone remodeling resulting from implantation. Around three kinds of implants, the decrease of granulation tissue volume, the formation of bone marrow space, and an obvious reduction of osteoblastic activity were noticed. In BIO implants, loose or dense fibrous tissue was interposed between new bone and implants with little direct bone contact with implant surfaces (Fig. 12A). However, three kinds of interfaces, fibrous, bone marrow and bone contact interfaces, were observed in FFX implants (Fig. 12B \& C). The interfaces of HAC implants showed continuous bone contact without any interposition of fibrous tissue (Fig. 12D).

Regenerating nerves also were found in the bone marrow near the implants (Fig. 13). Their diameter was larger and their number was greater than what was found in the one week case (Fig. 14). In this stage, the distribution of nerve fibers became different among the three kinds of implants. A few nerve terminals were found in fibrous tissues in the interface of BIO implants and in some interfaces of FFX implants (Fig. 15).

At three months, the bony trabeculi near the implants were more mature than the one 

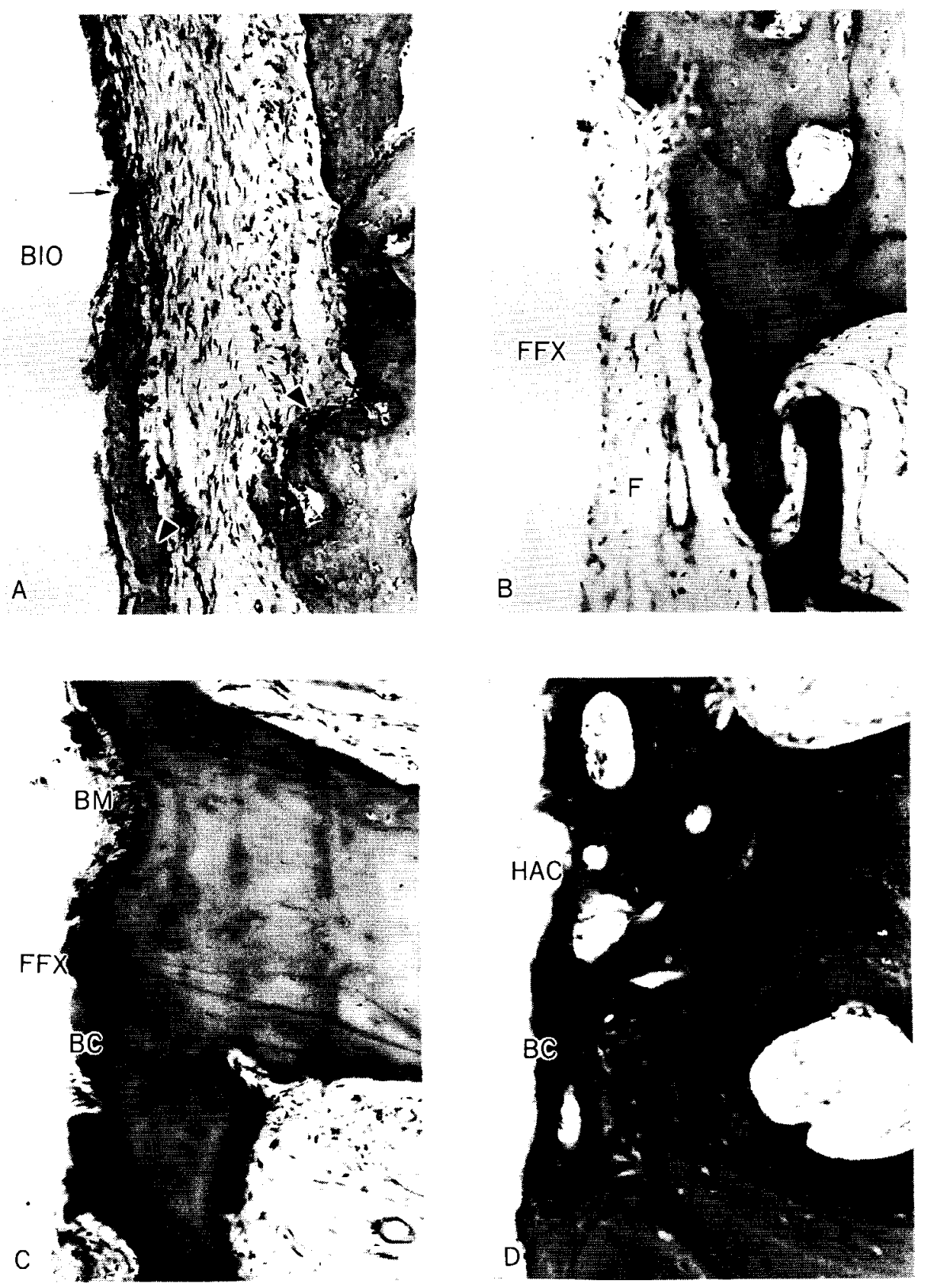

Fig. 12 Light micrograph of the implant interface in 1 month's case.

$\mathrm{A}$, in BIO implant, laminal bone (arrow head) accomplied around the implant but fibrous tissue (arrow) interposed between bone and implant; B \& C, in FFX implant, three kinds of interfaces, fibrous $(F)$, bone marrow $(B M)$ and bony contact (BC) interface, were found. $\mathrm{D}$, in HAC implant, a continuous bony contact (BC) without any interposing of fibrous tissue. (Original magnification $\times 50$, HE staining)

month specimens and the bone marrow showed fatty change (Fig. 16) of the sort seen in the three month specimen after tooth extraction. The relationship between different implants and surrounding tissue and the distribution of nerve fibers around implants remained the same as that in the one month specimens (Fig. 17, $18 \& 19$ ). The number of nerve fibers increased and some large nerve bundles also were detected in some cases (Fig. 16). Nerve terminals also were found in the interface of implants and surrounding bone marrow spaces, 


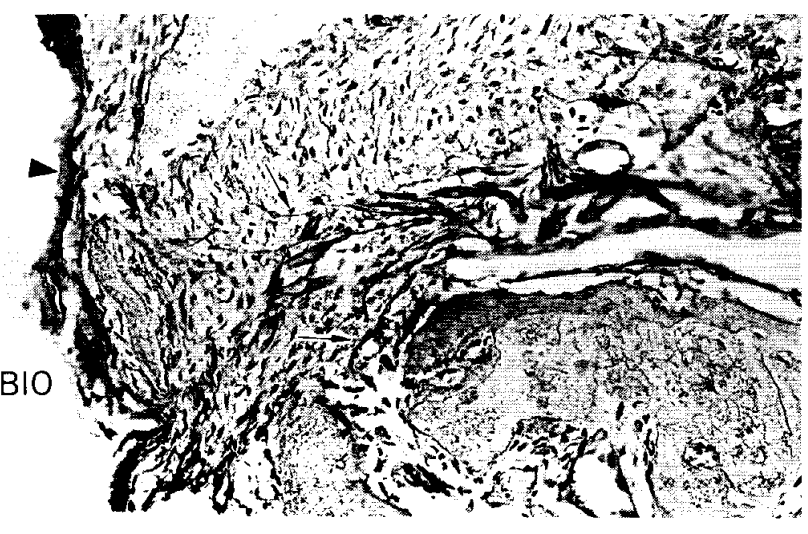

Fig. 13 Light micrograph of the regenerating nerves 1 month after implantation.

The regenerating nerves (arrow) grew toward the fibrous interface (arrow head) of $\mathrm{BIO}$ implant. (Original magnification $\times 50$, nerve staining)

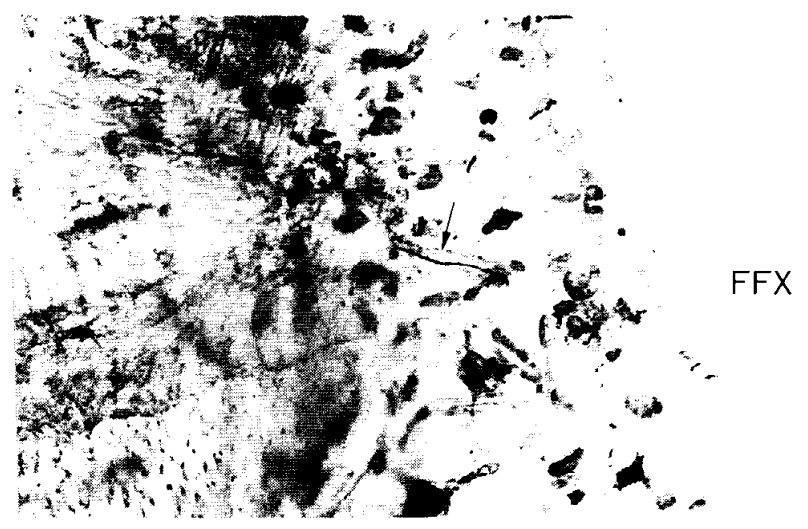

Fig. 15 Light micrograph of the nerve terminal (arrow) in the fibrous interface of a FFX implant 1 month after implantation. (Original magnification $\times 200$, nerve staining)

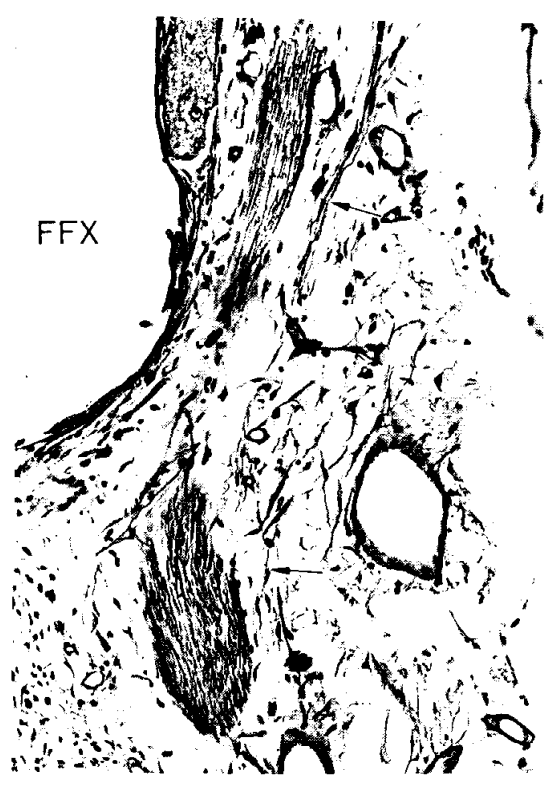

Fig. 14 Light micrograph of the regenerating nerve bundle (arrow) near the FFX implant 1 month after implantation. (Original magnification $\times 50$, nerve staining)

but they exhibited different shapes in the fibrous tissue interface and in the bone marrow space. In the bone marrow space, nerve terminals always were single and linear (Fig. 20-A), but in the fibrous interface, they always were branched (Fig. 20-B).

\section{Reconstruction of nerve tissue in three-dimensional picture}

In the picture of the reconstructed specimen three months after extraction, an ascending trunk extended from inferior alveolar nerve to gingival mucosa. Nerve fibers were sparse within this reconstructed specimen (Fig. 21).

In the three month specimens, reconstructions of nerve fiber in three kinds of implants (Fig. 22-A, B, C) showed a peri-implant concentration of nerve fibers. Nerve trunks distributed around implants also were seen to make a detour along all three kinds of implants passing from the inferior alveolar nerve to the oral mucosa side or from the distal to the 


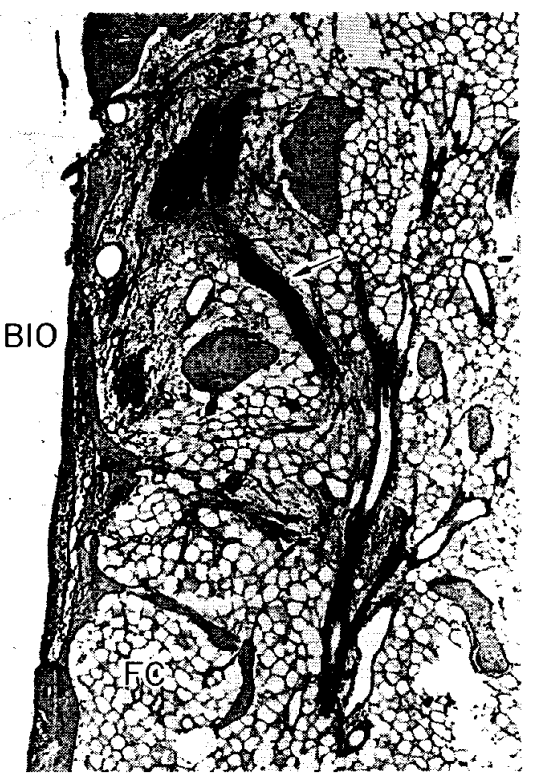

Fig. 16 Light micrograph of the whole view in peri-implant area 3 months after implantation. A large ascending nerve bundles (arrow) run near the BIO implant. Bone marrow showed fatty change (FC) just like what Fig. 5 showed. (Original magnification $\times 10$, nerve staining)

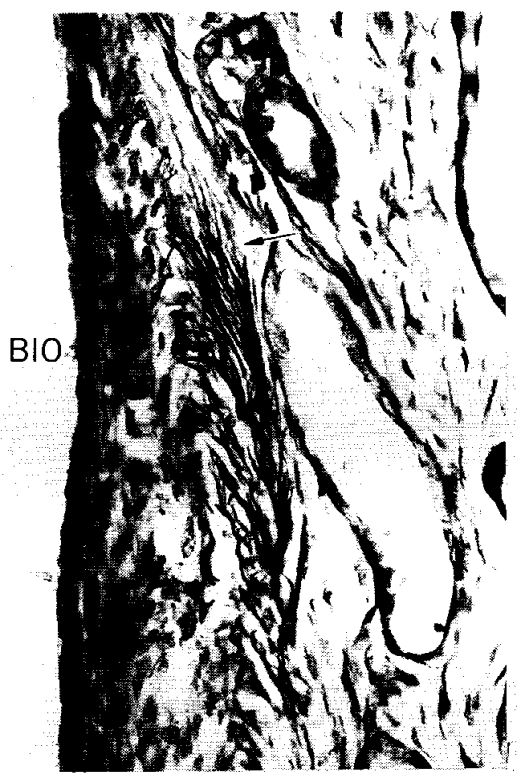

Fig. 17 Light micrograph of nerve fibers (arrow) existed in fibrous interface of $\mathrm{BIO}$ implant 3 months after implantation. (Original magnification $\times 100$, nerve staining)
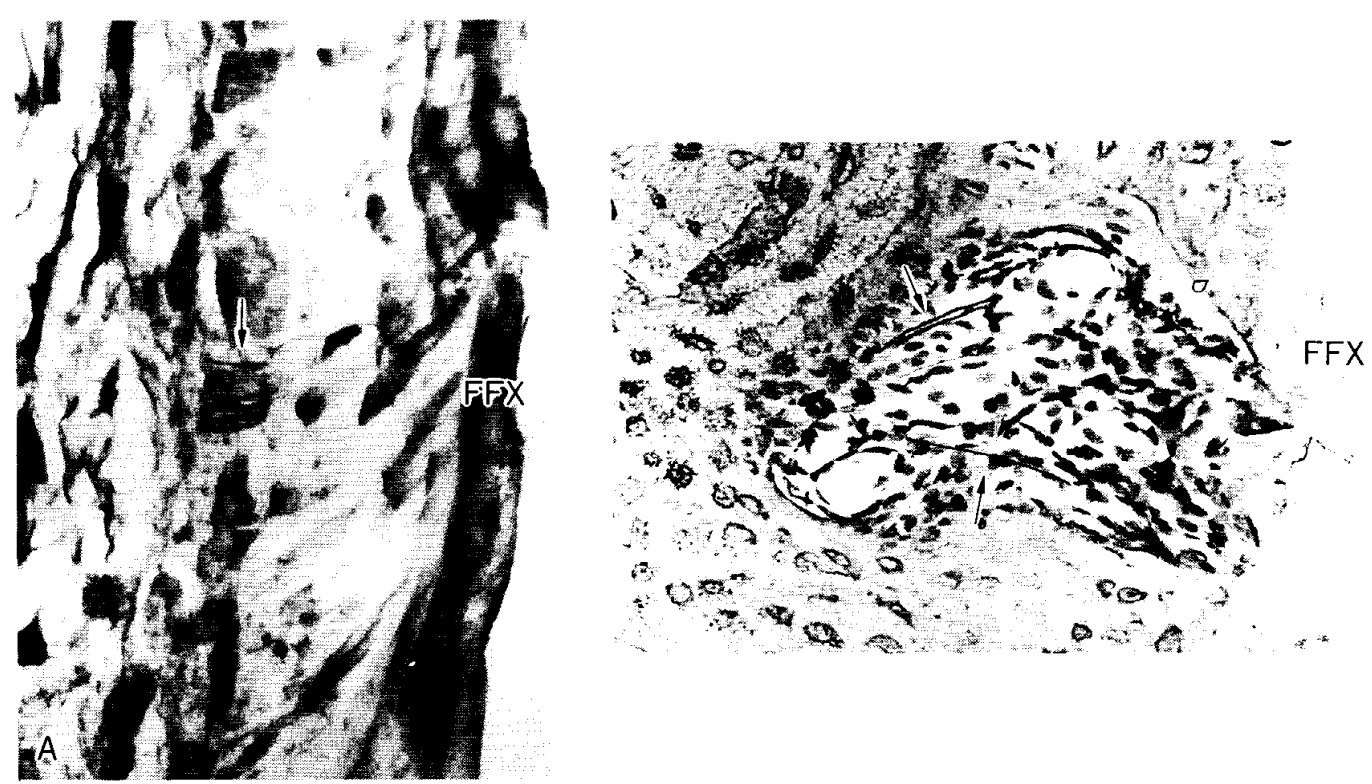

Fig. 18 Light micrograph of the nerve fibers around the FFX implant 3 months after implantation.

A, nerve fibers (arrow) existed in the fibrous interface of a FFX implant. ( $\times 200$, nerve staining) and $B$, nerve fibers (arrow) existed in the bone marrow interface of a FFX implant. $(\times 100$, nerve staining $)$ 


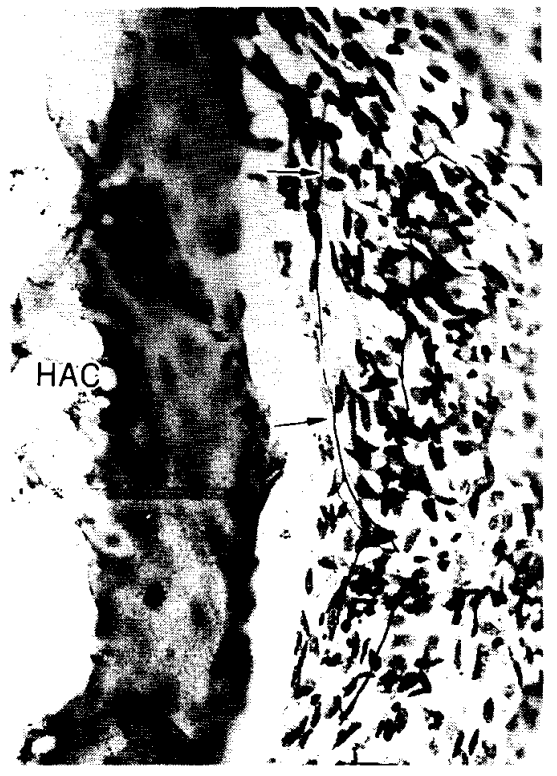

Fig. 19 Light micrograph of nerve fibers (arrow) in the bone marrow space of a HAC implant 3 months after implantation. (Original magnification $\times 80$, nerve staining)

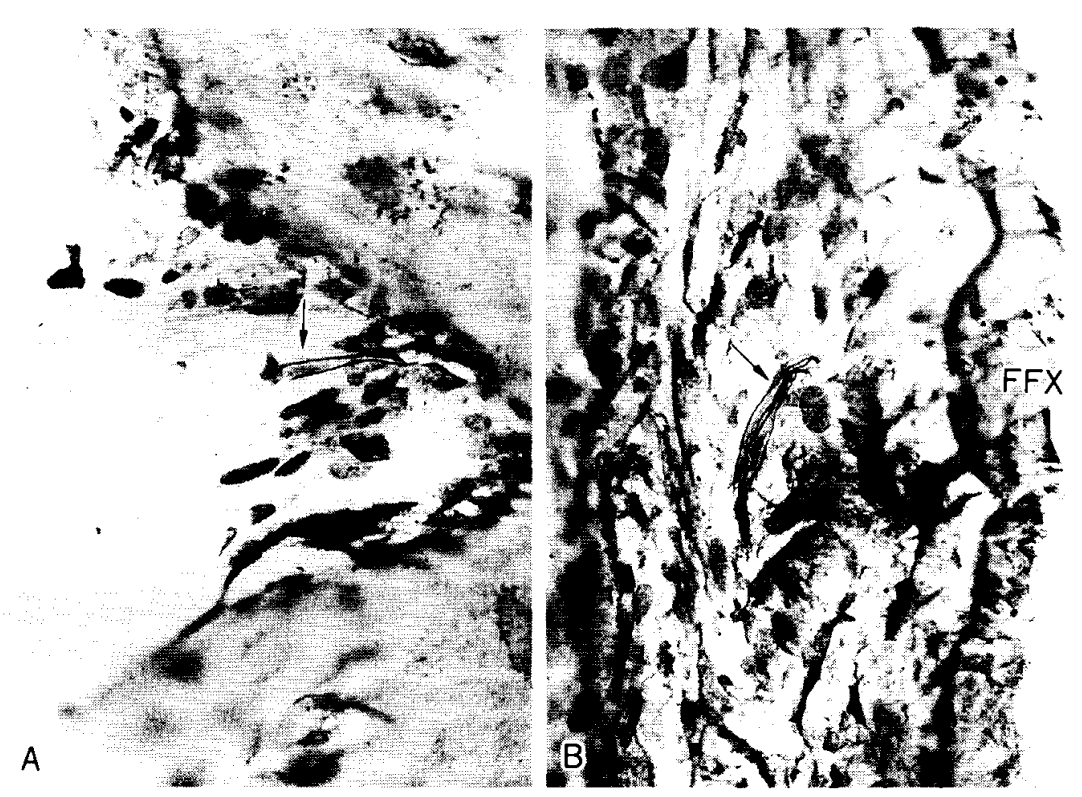

Fig. 20 Light micrograph of the nerve terminals (arrow) in bone marrow space (A, $\times 100$, nerve staining) and in the fibrous tissue (B, $\times 160$, nerve staining) around 3 months' implant.

mesial.

Two different pattern of nerve fibers were detected among the three kinds of implants. One was nerve fibers forming a membrane-like distribution found only in BIO implants (Fig. 22-A) and the other was that of ascending nerve trunks which were only found near FFX and BIO implants (Fig. 22-A, B).

\section{Histomorphometric findings}

Bone Contact Ratio - After estimating the BCR of three months' sections, averages of $78.09 \%$ in HAC implants, $44.41 \%$ in FFX implants and $8.40 \%$ in BIO implants were obtained. They showed a statistical difference $(\mathrm{p}<0.01)$ from each other; the graph of the BCR is illustrated in Figure 23.

Nerve density - Within an area of $200 \mu \mathrm{m}$ distance from the implants, means of ND (Fig. 24), $0.83 \pm 0.35\left(\mu \mathrm{m} / \mathrm{mm}^{2}\right)$ in HAC implants, $1.46 \pm 0.81\left(\mu \mathrm{m} / \mathrm{mm}^{2}\right)$ in FFX implants and $1.87 \pm 0.82\left(\mu \mathrm{m} / \mathrm{mm}^{2}\right)$ in BIO implants, were obtained; there is no significant statistical difference between the three kinds of implants.

There was a correlation $(\mathrm{R}=0.58 ; \mathrm{p}<0.01)$ between the $\mathrm{BCR}$ and ND after measuring 120 sections. The regressive graph showing this correlation is seen in Figure 25 . This kind of relationship also was found between the average $\mathrm{BCR}$ and $\mathrm{ND}$ in every block $(\mathrm{R}=0.63 ; \mathrm{p}<$ 0.05). The regressive graph showing the correlation of average BCR and ND is illustrated in Figure 26. The observation that the less the bone contact with implants, the more nerve fibers there are, applied not only to each section but also to each implant. 


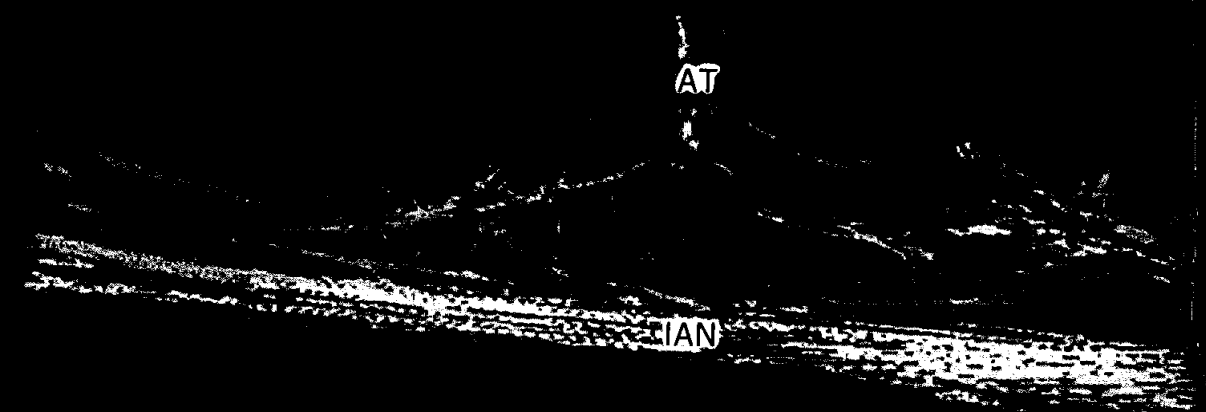

Fig. 21 Reconstructed pictures of the nerve tissues 3 months after extraction.

AT: ascending trunk; IAN : inferior alveolar nerve; OM: Oral mucosa; $\mathrm{M}$ : mesial side ; D : distal side.

\section{$\mathbf{M}$}
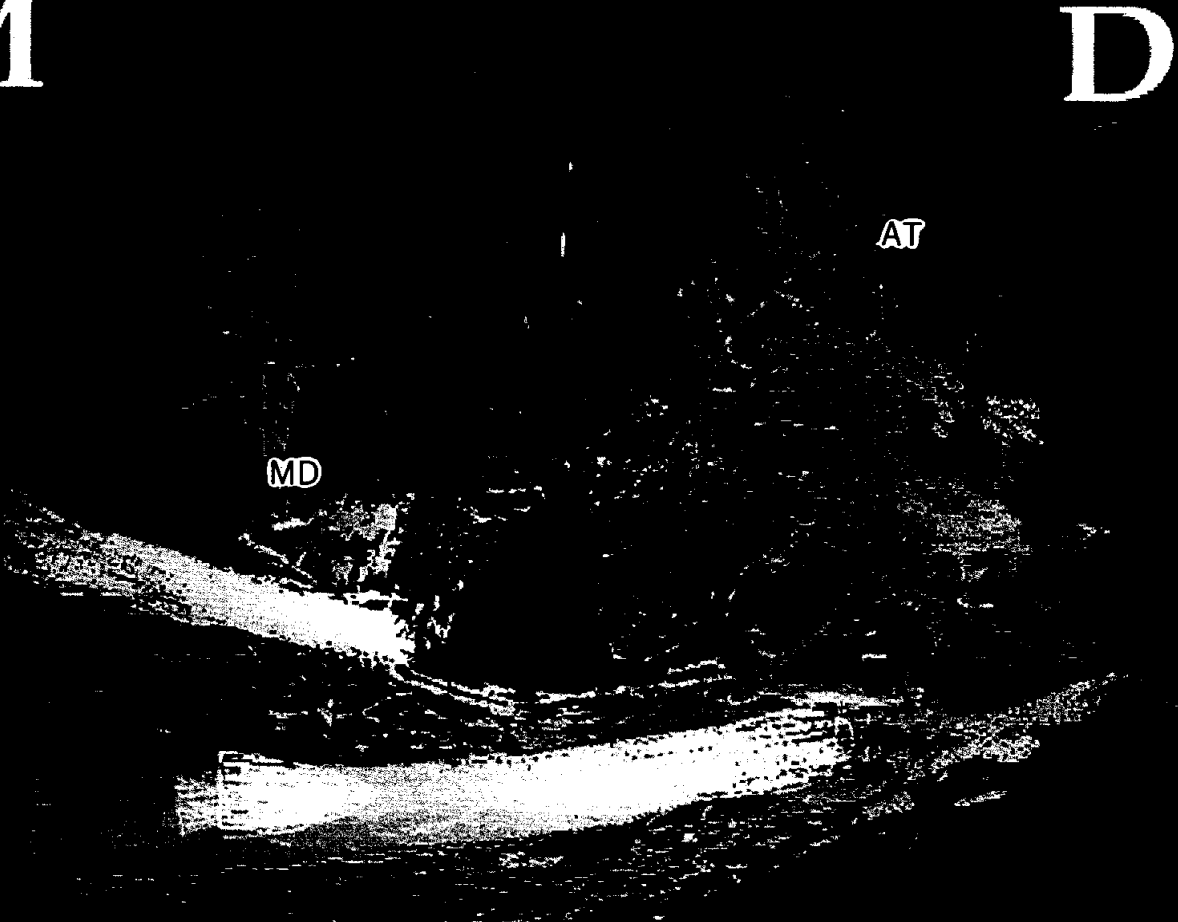

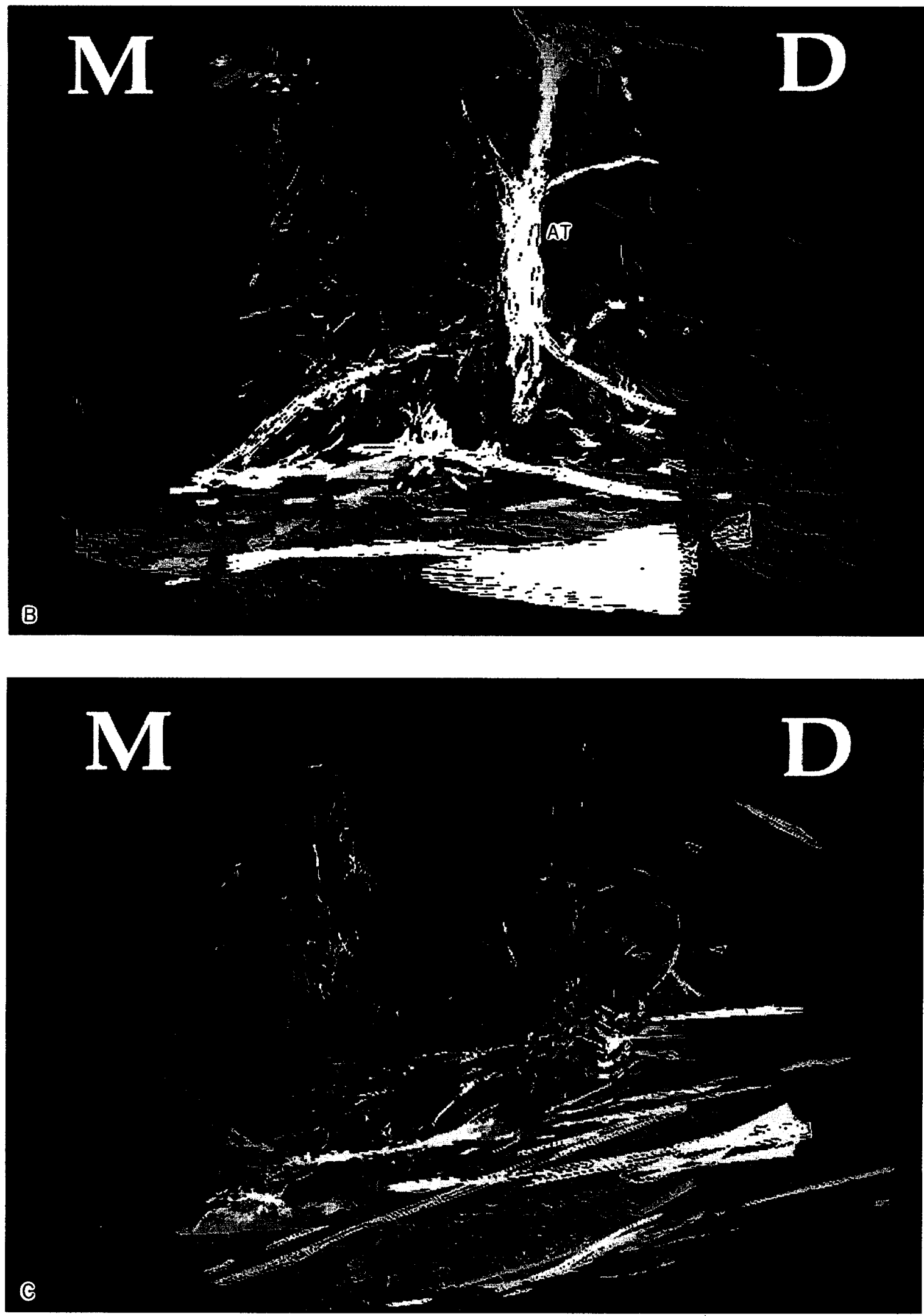

Fig. 22 Reconstructed pictures of the nerve tissues 3 months after implantation. A, BIO implant ; B, FFX implant ; C, HAC implant.

AT : ascending trunk; MD: Membrane-like distribution; $\mathrm{M}$ : mesial side of the implant; $\mathrm{D}$ : distal side of the implant. 


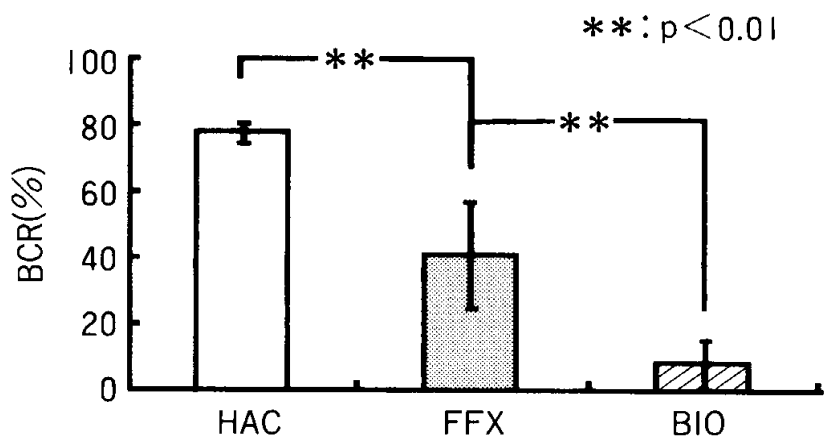

Fig. 23 Bone contact ratio in three kinds of implants.

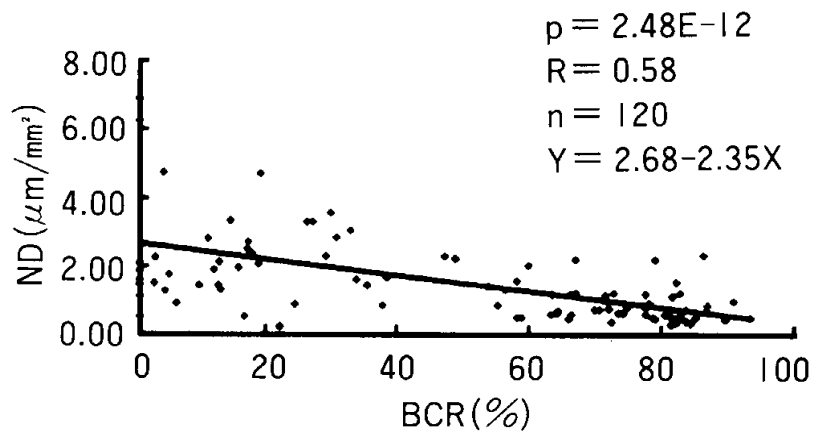

Fig. 25 The correlation between bone contact ratio and nerve density in 120 sections.

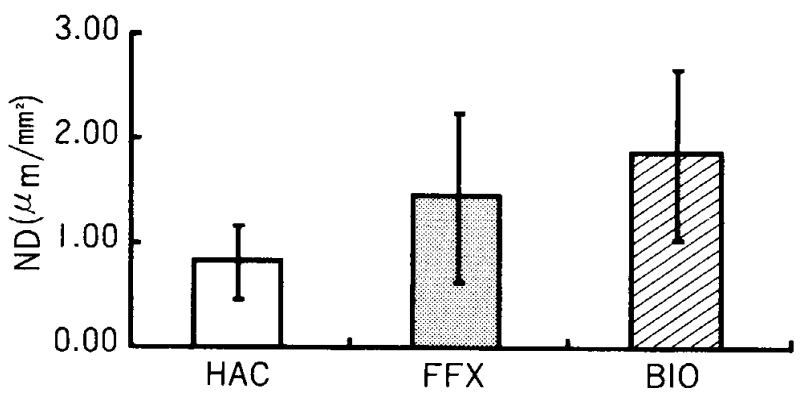

Fig. 24 Nerve density in three kinds of implants.

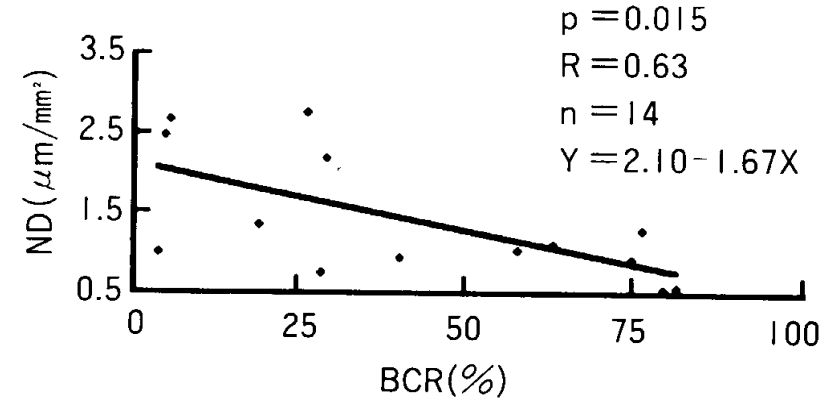

Fig. 26 The correlation between the average of bone contact ratio and the average of nerve density.

\section{Discussion}

In the present study, the regeneration of nerve fibers was examined by histologically comparing cases after implantation with controls and by evaluating the peri-implant concentration of nerve fibers on reconstructed pictures (Fig. 22-A, B, C). Furthermore, the finding that intact nerve fibers were very close to implants is important evidence of nerve regeneration around these devices. Because if they were distributed so close to the implants, they would degenerate or disappear after implantation, and then, only regeneration would enable them to appear once again in peri-implant area.

Histological studies reported by Weiner et al. (1995) ${ }^{22)}$ and Sawada et al. (1993) ${ }^{23)}$ stating that there were few nerve fibers in peri-implant areas seems to be questionable, because there are many neurophysiological experiments ${ }^{6,12,15-21)}$ confirming the presence of nerve-input systems around implants. In fact, the present study shows implantation has the same effect as the extraction of natural teeth. That is to say, after the injury from tooth extraction, nerve fibers of PDL are reduced in numbers, then regenerate (Fig. 27). Hansen (1980) ${ }^{30)}$ suggested that after tooth extraction, both nerve cell bodies in trigeminal ganglion and nerve fibers in alveolar bone recovered, although the number of nerve fibers in alveolar bone 


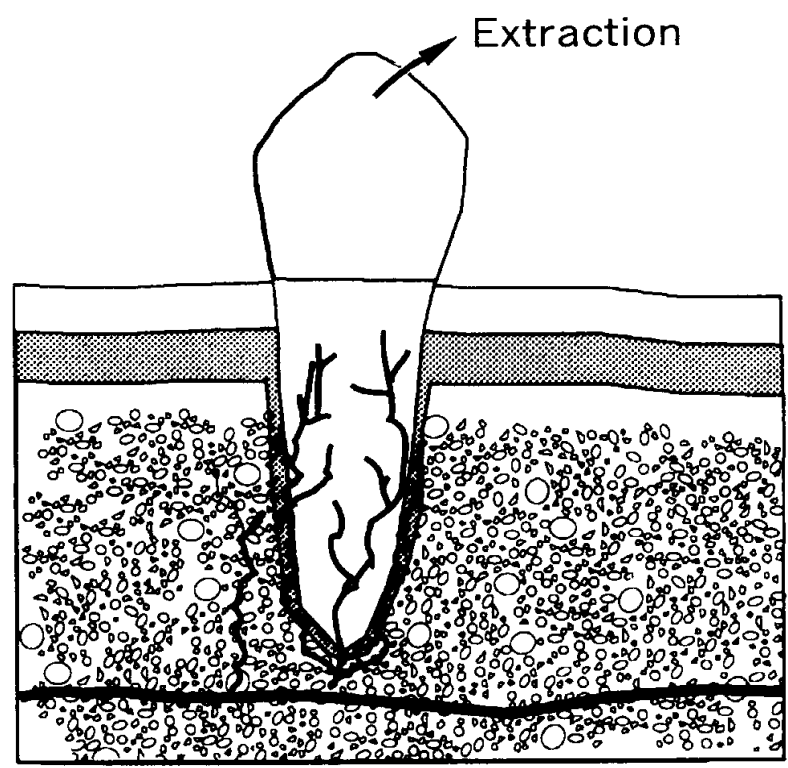

First degeneration \& First regeneration

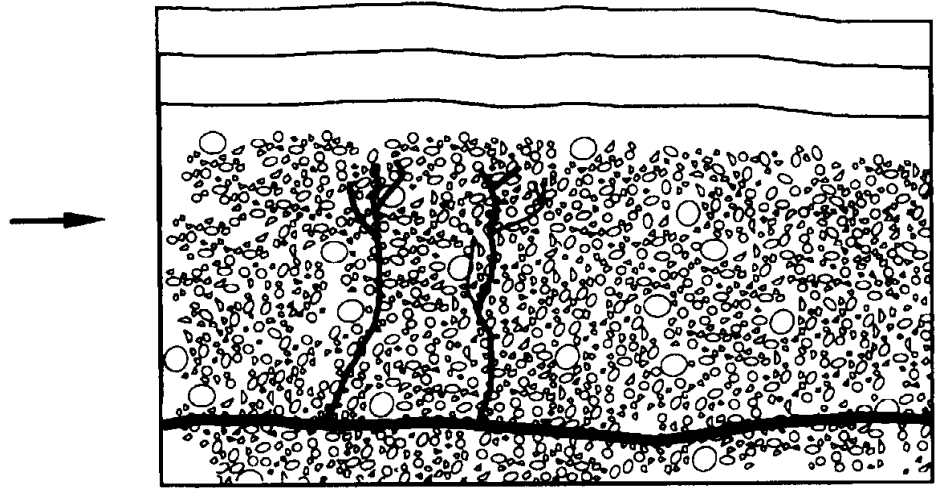

Second degeneration
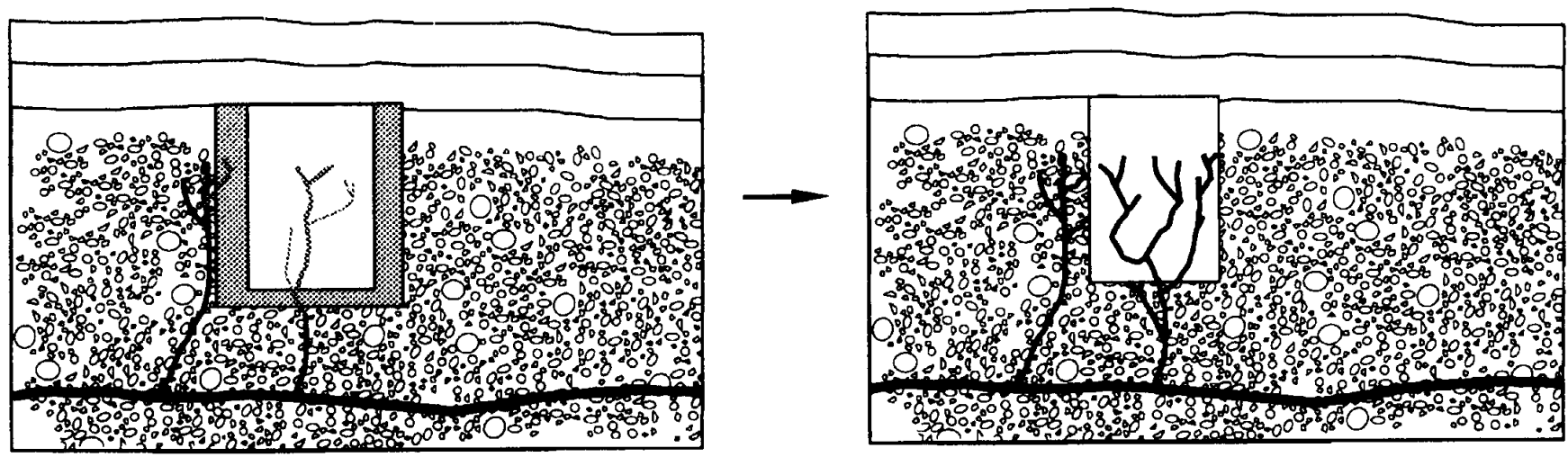

Fig. 27 Illustration to show the fate of nerve tissue from extraction to the healing of implantation.

ultimately decreased. Linden and Scott $(1989)^{31)}$ also concluded that neurons with cell bodies in both trigeminal ganglion and mesencephalic nucleus can reinnervate the new softtissue sites after extraction. Recently, growth-associated protein (GAP-43) related to neural development and regeneration was detected in mechanoreceptors and in free nerve endings in PDL and dental pulp ${ }^{32}$. Immunocytochemistry indicated a high potential for neuroplasticity of periodontal and pulpal nerve fibers. In accordance with the above findings, it appears that nerve fibers originating from the trigeminal nerve and being characterized by high neuroplasticity will regenerate and reinnervate peri-implant areas.

Histological findings in the present experiment about the fate of periodontal nerve fibers after extraction coincided with the observation of Mason et al. $(1993)^{28)}$, who traced the chronological changes after extraction by reconstructing the nerve fibers. Nerve fibers 
returned after extraction and formed an ascending trunk at the central portion of the extraction socket. Such a trunk also was seen in sections three months after extraction and three months after implantation. These nerve trunk influenced the distribution of nerve branches originating from the trunks. In other words, the relationship between the anatomic position of the nerve trunk and the site of implantation seems to be a factor in the unequal distribution of nerve fibers in the peri-implant area. This unequal distribution can explain why a different pattern of the mouth closing reflex occurred when stimulation was applied from different directions in Ichikawa's (1993) neurophysiological study ${ }^{21)}$.

In the present study, the observation was terminated at three months after implantation, when implants still remained submerged in gingiva. No superstructure was restored and no occlusal force was applied. So the results only showed what happened during the three month healing phase. From the present findings, the ND is strongly related to the BCR and to the degree of fatty change in the marrow. Although implants remained in the alveolar bone for a long time without functional stimulation, it was postulated that depending upon the maturation or aging of bone tissue, the density of nerves fibers will decrease, just as in the study by Sawada et al $(1993)^{23}$. It also was posited that functional stimulation ${ }^{33)}$ following the installation of superstructure will produce some changes in the nerves fiber of the periimplant area. However, this hypothesis needs to be proved.

The one week stage, when osteoblasts expressed different patterns of osteoid formation in different implants and nerve fibers were regenerating actively, was thought to be an important time to determine the distribution of nerve fibers. At some sites of the FFX implants and the BIO implants, the advancing pattern of bone formation was found to be only from the side of old trabeculae to the surface of implants. Before the new bone reached the surface of implants, nerve fibers had already entered the fibrous interfacial space. Employing the same advancing pattern mentioned above, osteoblasts covered the surface of HAC implants with osteoid first so that there was no space for nerve fibers to grow into the interface of implants. For this reason, nerve fibers were distributed only in the bone marrow space in the vicinity of the HAC implants. The tissue dynamics of this stage explain why the distribution of nerve fibers will be different in the specimens one month after implantation.

Maeda et al. $(1990)^{8}$ listed sensory nerve terminals in the PDL: free nerve endings and specialized nerve endings (sensory receptors), which consist of Ruffini-like endings, coiled nerve endings, spindle-shaped nerve endings, and expanded nerve endings. In the present study, only free nerve endings with tree-like ramifications were found. They formed short bundles in the fibrous interface and single fibers in the bone marrow space. The dimension of most regenerating nerve fibers near implants was fine. When the nerves in the implant model are compared to those in natural teeth, it becomes apparent that in the model there are no specialized receptors and that the regenerated nerves mostly are fine fibers. These two conditions suggest that the regenerated nerves might relatively have a high threshold ${ }^{6,15}$ ) and a low conduction speed ${ }^{20)}$. To elicit definitive evidence of the absence of specialized receptors and the myelinated structures adjacent to implants will require EM observation of 
this region.

According to Keller's report $(1996)^{15)}$, the threshold for tactile sensitivity perceived via dental implants remains unchanged during a healing phase of 3 months. He gave some reasons for this result: 1) possible changes taking place may be below the detection level of the method used; 2) actual changes do indeed take place, but may be limited to the first week following implant placement. However, in the present study, the histological changes of nerve fibers were detected during the three month healing phase. It is obvious that degenerated nerves will not show the same sensation as do regenerated nerves. Therefore, it is concluded that tactile sensitivity varies during this phase.

Quantitative differences in nerve fibers around the different implants were evaluated by calculating ND. Because of the great ND deviation resulting from severe deviation of $\mathrm{BCR}$ in FFX implants and because of the existence of a layer of fibrous tissue (Fig. 12) at the BIO interface, where no nerve fiber was found, no statistical difference in ND could be found between different implants (Fig. 22). However, there appeared a negative correlation between the $\mathrm{BCR}$ and $\mathrm{ND}$ both in average value (Fig. 24) and local calculating value (Fig. 23), when all surfaces of implants were considered. The higher the $\mathrm{BCR}$ is, the lower the number of nerve fibers becomes. Being as low as 0.58 and 0.63 in correlation coefficients, BCR was thought not to be the direct factor in determining ND. The kind of tissue bed developing around implants was regarded as the main factor affecting ND.

Past studies on sensory physiology of implants did not evaluate the effects of using different materials. The histological results of the present study suggest that there might also be differences in neurophysiological functions when different implants are used. Since the neurophysiological function will be related to what kind of occlusion the implantsupported crown is designed for, checking the neurophysiological function of different implants will be essential.

According to the osseointegration concept ${ }^{1)}$, the best implants are those that can gain the greatest bone contact. The result of $\mathrm{BCR}$ in this study showed HAC as having a better BCR than the other two $(\mathrm{P}<0.01)$ (Fig. 21) in the three month specimen. There are many reports of the alleged superiority of $\mathrm{HAC}$ in $\mathrm{BCR}^{2,34,35)}$ and suggesting that $\mathrm{HAC}$ implants be substituted for titanium implants. But according to the correlation of BCR to ND obtained in the present study, the implant that has good BCR seems not to be a good one in terms of sensory input. The HAC implant will result in a problem of overloading because it lacks a good sensory transmitting system. The shortcoming in the HAC implant suggests that they are not necessarily the best choices in all cases.

On the whole, there are three factors determine the distribution of nerve fibers around implants: 1) what kind of tissue bed develops around the implant; 2) how many nerve fibers exist before implantation; 3 ) how far the ascending trunk is from the implant. If nerve regeneration around implants is the criterion for successful implantation, the following is advised: to use an implant that has an amount of $\mathrm{BCR}$, not necessarily the highest BCR, that will allow the regeneration of nerve fibers; if possible, to insert the implant at the 
precise position where the extracted tooth sat, because the sound nerve trunks that innervated the PDL before extraction will remain; to do an immediate implantation into the extraction socket, because it will conflate two separate injuries of nerve fibers in the PDL.

\section{Conclusions}

1. It is clear that nerve fibers eventually are present in abundance around the implant. These fibers originated from what innervated the PDL before and suffered from injury at first by extraction and by implantation, then regenerated to reinnervate the peri-implant area. It suggests that the surrounding soft tissue potentially can acquire a degree of sensitivity to external stimuli.

2 . The behavior of osteoblasts in bone formation influenced components of peri-implant tissue directly and influenced the distribution of nerve fibers in peri-implant area indirectly.

3 . The innervation density of nerve fibers showed negative correlation with the bone contact ratio $(\mathrm{P}<0.01)$. Furthermore, morphological and quantitative differences of nerve fibers were detected around different implant materials, suggesting that the composition of implants may influence the degree of recovery to sensation.

\section{Acknowledgments}

The Kyocera Company supplied the implant materials used in this study. The author greatly wishes to thank the director, Prof. Y. Uchida, Dr. T. Kojo and the staff of the Second Department of Prosthetic Dentistry, Kyushu Dental College, and Prof. H. Fukuyama and his staff in the Department of Oral Pathology, Kyushu Dental College for their help in writing this manuscript. The author also wishes to thank Buzen Rotary Club which provided economic support and, finally, his wife and parents who always greatly encouraged him.

\section{References}

1) Albrektsson, T. \& Jacobsson, M.: Bone-metal interface in osseointegration. J. Prosth. Dent. 57: 597607, 1987.

2) Jansen, J. A., van de Waerden, J. P., Wolke, J. G. \& de Groot, K. : Histologic evaluation of the osseous adaptation to titanium and hydroxyapatite-coated titanium implants. J. Biomed. Mater. Res. 25 : 973-989, 1991.

3 ) Suzuki, K.: The histological consideration on the interface of dental implant-bone. Matzumoto Shigaku. 19: 223-235, 1993. (in Japanese)

4 ) Jemt, T. \& Stalblad, P. -A.: The effect of chewing movements on changing mandibular complete dentures to osseointegrated overdentures. J. Prosth. Dent. 55: 357-361, 1986.

5 ) Haraldson, T., Jemt, t. \& Stalblad, P. -A. : Oral function in subjects with overdentures supported by osseointegrated implants. Scand. J. Dent. Res. 96: 235-242, 1988.

6 ) Mericske-Stern, R., Hofmann, J., Wedig, A. \& Geering, A. H.: In vivo measurements of maximal occlusal force and minimal pressure threshold on overdentures supported by implants or natural roots : a comparative study (Part 1). Int. J. Oral. Maxillofac. Implants. 8: 641-649, 1993.

7 ) Isidor, F. : Histological evaluation of peri-implant bone at implants subjected to occlusal overload or plaque accumulation. Clin. Oral Implant. Res. 8: 1-9, 1997. 
8 ) Maeda, T., Kannari, K., Sato, O. \& Iwanaga, T.: Nerve terminals in human periodontal ligament as demonstrated by immunohistochemistry for neurofilament protein (NFP) and S-100 protein. Arch. Histol. Cytol. 53 : 259-265, 1990.

9 ) Millar, B. J., Halata, Z. \& Linden, R. W.: A possible explanation for the response characteristics of multi-tooth periodontal ligament mechanoreceptors in the cat. Anat. Embryol. 190: 445-452, 1994.

10) Linden, R. W. \& Scott, B. J.: Distribution of mesencephalic nucleus and trigeminal ganglion mechanoreceptors in the periodontal ligament of the cat. J. Physiol. (Lond.). 410:35-44, 1989.

11) Linden, R. W., Millar, B. J. \& Halata, Z.: A comparative physiological and morphological study of periodontal ligament mechanoreceptors represented in the trigeminal ganglion and the mesencephalic nucleus of the cat. Anat. Embryol. 190: 127-135, 1994.

12) Jacobs, R. \& van Steenberghe, D.: Role of periodontal ligament receptors in the tactile function of teeth: a review. J. Periodont. Res. 29: 153-167, 1994.

13) Loescher, A. R., Holland, G. R. \& Robinson, P. P.: The distribution and morphological characteristics of axons innervating the periodontal ligament of reimplanted teeth in cats. Arch. Oral Biol. 38: 813-822, 1993.

14) Loescher, A. R. \& Robinson, P. P.: Characteristics of periodontal mechanoreceptors supplying reimplanted canine teeth in cats. Arch. Oral Biol. 36:33-40, 1991.

15) Keller, D., Hammerle, C. H. \& Lang, N.P.: Thresholds for tactile sensitivity perceived with dental implants remain unchanged during a healing phase of 3 months. Clin. Oral Implant. Res. 7: 48-54, 1996.

16) Stuge, U., Brodin, P. \& Bjornland, T.: Masseter muscle reflex evoked by tapping on osseointegrated Frialit implants. Int. J. Oral. Maxillofac. Implants. 8: 650-654, 1993.

17) Ulrich, R., Muhlbradt, L., Mohlmann, H., Schmid, H. \& Hoss, A.: Qualitative mechanoperception of natural teeth and endosseous implants. Int. J. Oral. Maxillofac. Implants. 8: 173-178, 1993.

18) Bonte, B., Linden, R. W., Scott, B. J. \& van Steenberghe, D.: Role of periodontal mechanoreceptors in evoking reflexes in the jaw-closing muscles of the cat. J. Physiol. (Lond). 465: 581-594, 1993.

19) Yoshida, K.: Studies on tactile-sensation threshold in surrounding tissues of osseointegrated implant. Shika Gakuho. 88: 1603-1642, 1988. (in Japanese)

20) Kondo, N.: Plasticity of mechanoreceptive afferents in case of endosseous implants of the dog. J. Hiroshima Dent. Soc. 20: 1-18, 1988. (in Japanese)

21) Ichikawa, T., Nouchi, A., Shimada, K. \& Kusakari, H.: Neural control of endosseous implantmasseteric reflex in the cat. J. Jpn. Prosthodont. Soc. 37: 376-390, 1993. (in Japanese)

22) Weiner, S., Klein, M., Doyle, J. L. \& Brunner, M. : Identification of axons in the peri-implant region by immunohistochemistry. Int. J. Oral. Maxillofac. Implants. 10:689-695, 1995.

23) Sawada, M., Kusakari, H., Sato, O., Maeda, T. \& Takano, Y.: Histological investigation on chronological changes in peri-implant tissues, with special reference to response of nerve fibers to implantation. J. Jpn. Prosthodont. Soc. 37: 144-158, 1993. (in Japanese)

24) D'Souza, S. M., MacIntyre, I., Girgis, S. I. \& Mundy, G. R.: Human synthetic calcitonin gene-related peptide inhibits bone resorption in vitro. Endocrinology. 119: 58-61, 1986.

25) Zaidi, M. et al.: Calcitonin gene-related peptide inhibits osteoclastic bone resorption: a comparative study. Calcif. Tissue Int. 40: 149-154, 1987.

26) Nishio, Y. \& Gen, E.: POI system implant. Quint. Dent. IMPLANTOL. 4: 83-91, 1997. (in Japanese)

27) Kitamura, K., Itaka, M., Beppu, M. \& Nagamatsu, K.: Microscopical study of the innervation in the oral tissue of various animals (part II). J. Kyushu Dent. Soc. 12: 171-176, 1958. (in Japanese)

28) Mason, A. G. \& Holland, G. R.: The reinnervation of healing extraction sockets in the ferret. J. Dent. Res. 72 : 1215-1221, 1993.

29) Johnson, P. C. \& Asbury, A. K. : Pathology of peripheral nerve. W. B. Saunders Comoany, 
Philadelphia, 1978, 50-71.

30) Hansen, H. : Neuro-histological reactions following tooth extractions. Int. J. Oral Surg. 9: 411-426, 1980.

31) Linden, R. W. \& Scott, B. J.: The effect of tooth extraction on periodontal ligament mechanoreceptors represented in the mesencephalic nucleus of the cat. Arch. Oral Biol. 34: 937-941, 1989.

32) Maeda, T. \& Byers, M. R.: Different localizations of growth-associated protein (GAP-43) in mechanoreceptors and free nerve endings of adult rat periodontal ligament, dental pulp and skin. Arch. Histol. Cytol. 59 : 291-304, 1996.

33) Ohshima, K., Noda, T. \& Maeda, T.: Functional stimuli such as occlusal forces induce the maturation of the nerve endings. Quintessence. 16: 1006-1012, 1997. (in Japanese)

34) Hayashi, K., Uenoyama, K., Matsuguchi, N. \& Sugioka, Y.: Quantitative analysis of in vivo tissue responses to titanium-oxide- and hydroxyapatite-coated titanium alloy. J. Biomed. Mater. Res. 25 : 515-523, 1991.

35) Shirota, T., Donath, K., Matsui, Y., Ohno, K. \& Michi, K.: Reactions of bone tissue in old rats to three different implant materials. J. Oral Implantol. 20: 307-314, 1994. 


\title{
各種インプラントの周囲における \\ イヌ神経分布の組織学的研究
}

\author{
王益暉 \\ 九州歯科大学大学院歯学研究科補緅学第 2 専攻（指導：内田康也教授） \\ 九州蒾科大学口胿病理学講座（指導：福山 宏教授）
}

平成 9 年 8 月 25 日受理

菌科用インプラント材の具備すべき条件を検討する事 項の一つに，天然歯が有する機能の有無が挙げられる. 特にインプラント周囲組織における感覚入力のメカニズ ムについて解明することは重要な課題であり, 神経生理 学的ならびに神経組織学的な検討を加える必要がある. そこで, 本研究では, 拔㐘後 3 力月経過した成犬の下顎 骨内に単結晶アルミナセラミックインプラント, 陽極酸 化被膜形成チタン合金製インプラント，ヒドロキシアパ タイト被覆チタン合金製の 3 種類のシリンダータイプイ ンプラント体を埋入し, 非機能下でのインプラントの埋 入後 3 力月までの治癒経過に伴う神経線維の動態につい て病理組織学的な検索を行った。 また, 術後 3 力月例で は神経線維の分布状態について三次元の画像で再構築を 試み, さらに骨接触率と神経支配密度の組織形態計測を 施した.この研究の結果により, 以下の結論を得た.

1) 各種埋入インプラント体周囲には神経線維の存在
が明らかに認められた。この神経線維は既存の神経線維 から二度にわたる傷害後に，分布してきた再生神経と考 えられる，再生神経の一部はインプラント体を支持する 骨に接しながら終末として分布を示すことから，インプ ラント周囲の感覚を担っている可能性が示された。

2) イプラント体埋入後 1 週から 1 カ月の間のインプ ラント体に対する骨形成の様式は，3 種類とあ異なるた めに, 3 力月後の骨接触率に差が認められた。一方, 骨形 成様式の差により, 再生神経線維の分布様式も異なって いた.

3）神経支配密度と骨接触率とが逆相関関係を示した こと $(\mathrm{p}<0.01)$ と, 3 種類のインプラントの間に神経線 維の形態的，ならびに量的な差異が認められたことか らこれらのインプラントの間には感覚機能の差異が存 在する可能性が示唆された。 